\title{
DSC and TGA Measurements of Room Temperature Ionic Liquids (RTILs) Containing Ammonium Alum or Aluminum Nitrate with Amide Compounds
}

\author{
Hadi M. A. Abood ${ }^{1}$ and Huda S. Abid \\ Department of Chemistry, College of Science, Al-Nahrain University, Baghdad-Iraq. \\ E-mail: drha85@yahoo.co.uk.
}

\begin{abstract}
Characterization of some room temperature ionic liquids (RTILs) as thermal storage media and heat transfer fluids in thermal applications were investigated. Five ionic liquids prepared from ammonium alum $\mathrm{NH}_{4} \mathrm{Al}\left(\mathrm{SO}_{4}\right)_{2} \cdot 12 \mathrm{H}_{2} \mathrm{O}$ as inorganic salt with urea $\mathrm{NH}_{2} \mathrm{CONH}_{2}$ or acetamide $\mathrm{CH}_{3} \mathrm{CONH}_{2}$ as organic compounds, and aluminum nitrate salt $\mathrm{Al}\left(\mathrm{NO}_{3}\right)_{3} .9 \mathrm{H}_{2} \mathrm{O}$ either with urea or acetamide compounds in two mole ratios were investigated using Thermo-Gravimetric Analysis (TGA), Differential Scanning Calorimetry (DSC), X-ray diffraction (XRD), Fourier Transform Infrared (FTIR) spectroscopy and conductivity measurements. Thermo-physical properties such as enthalpy, heat capacity and thermal energy storage capacity were determined. It was found that ammonium alum: urea (USIL) in the mole ratio (1:5) and aluminum nitrate: acetamide (AN2IL) in the mole ratio (1:22) ionic liquids to be characterized with high density, wide liquid temperature range, high chemical stability, high heat capacity and high thermal energy storage capacity. Based on experimental results, it is concluded that ionic liquids could be considered as a candidate for liquid thermal storage media and heat transfer fluids.
\end{abstract}

Keywords: Heat storage, differential scanning calorimetry, Thermal applications, Thermo-physical properties, Room Temperature Ionic Liquid.

\section{Introduction}

The demand and supply gap for energy sources is widening day by day. The solar energy is mainly used in residential field (space heating and cooling, domestic water heating systems, etc.)[1,2]. In recent years, various materials were investigated for applications related to storage and transfer of thermal energy[3]. Properties like freezing point, decomposition temperature, density, heat of fusion, heat capacity and thermal energy storage capacity govern the suitability of materials to be used for thermal applications. The liquid range of a material for thermal energy storage (TES) is between its melting point and decomposition temperature.

Many applications have specific expectations from a Thermal Energy Storage (TES) material which makes it impossible to have a universal material for all thermal applications. The classical TES materials are rocks, water, thermal oil, organic and inorganic compounds. Rocks can be used as thermal storage materials[4] because they are not toxic, non-flammable, inexpensive and can act both as heat transfer surface and storage medium but its use as heat storage is more limited due to their low heat capacity $(\sim 0.9 \mathrm{~kJ} / \mathrm{kg} / \mathrm{K})$, low thermal conductivity $(\sim 6.6 \mathrm{~W} / \mathrm{m} / \mathrm{K})$ and unknown response to longterm thermal cycling. Water is the most popular heat transfer fluid. It has high latent thermal energy, high thermal conductivity, high specific heat and high density with moderate viscosity. The biggest difficulties for water as a heat transfer fluid are corrosiveness and limited range of temperature over which it can be used. Theoretical liquid range is between $0^{\circ} \mathrm{C}$ to $100{ }^{\circ} \mathrm{C}$, but the practical temperature range for water used as heat transfer fluid is much less than $100{ }^{\circ} \mathrm{C}$ because of the high vapor pressure at near boiling point which is the major downsides for thermal applications [5,6].

Several organic materials like paraffins, glycols and fatty acids are used for TES. However, volatility and inflammability have restricted the popularity of organic phase changing materials in thermal applications.

A variety of inorganic salts of alkali and alkaline earth metals find a place in thermal energy storage. Major disadvantages of inorganic materials are corrosiveness and low thermal stability. Thus, it has become 
imperative to combine organic and inorganic materials for thermal applications. Currently thermal oil and molten salt are used as liquid storage media. The main problems for oil media are the low decomposition temperature (e.g. $300{ }^{\circ} \mathrm{C}$ ) and for molten salt media it is its high melting point (e.g. $220{ }^{\circ} \mathrm{C}$ ). The low decomposing temperature limits the energy storage and high melting point can cause molten salt freezing in evening or cold weather, resulting in high operating costs [7].

Ionic liquids are liquid salts consist solely of ions (cations and anions) have melting point of $100^{\circ} \mathrm{C}$ or below. Ionic liquids possess a couple of unique features that allow the development of new highly specialized applications. Based on the experimental results, it was found that ionic liquids have excellent technical properties for the applications as liquid thermal storage media and heat transfer fluids in a solar thermal power plant. These properties include high heat capacity, wide liquid temperature range and high density. The combination of very low vapor pressure, good heat capacity, wide usable temperature range and high thermal stability allows the use of ionic liquids as heat transfer media at very low pressures or under vacuum[6-8]. Another properties contribute to the qualification of ionic liquids as liquid thermal storage media and heat transfer fluids were high chemical stability, non-volatility, high storage density, non-harmfulness and nonflammable.

The present paper aims to investigate; the suitability of some ionic liquids containing ammonium alum or aluminum nitrate with urea or acetamide for thermal energy storage (TES) and heat transfer fluid by studying their thermo-physical properties.

\section{Experimental work}

\subsection{Chemicals and general procedure:}

Ionic liquid was prepared by mixing a proper amount of hydrated aluminum nitrate $\mathrm{Al}\left(\mathrm{NO}_{3}\right)_{3} .9 \mathrm{H}_{2} \mathrm{O}$, (97\% obtained from $\mathrm{BDH})$ or hydrated ammonium alum $\mathrm{NH}_{4} \mathrm{Al}\left(\mathrm{SO}_{4}\right)_{2} .12 \mathrm{H}_{2} \mathrm{O}$, $(99.5 \%$ obtained from $\mathrm{BDH})$ either with urea $\mathrm{NH}_{2} \mathrm{CONH}_{2}$, $(99.5 \%$ obtained from THOMAS BAKER) or acetamide $\mathrm{CH}_{3} \mathrm{CONH}_{2}$, (98\% obtained from Fluka) were milled, mixed together and heated with gentle stirring until clear colorless liquids were obtained as follow:

1. Ionic liquid preparation with acetamide:

- Hydrated aluminum nitrate and acetamide were prepared in a range of two mole ratios of 1:2.4 and 1:22 respectively, were heated at a temperature of $50^{\circ} \mathrm{C}$ for $1 / 2$ hour or $80{ }^{\circ} \mathrm{C}$ for 1 hour.

Aluminum nitrate: acetamide of $2: 1$ mole ratio showed melting point of $26^{\circ} \mathrm{C}$, while $1: 1$ mole ratio gave higher melting point of $50{ }^{\circ} \mathrm{C}$. However, when the mole ratio of aluminum nitrate was smaller than acetamide gave much lower melting point of $\left(-20^{\circ} \mathrm{C}\right)$ for $1: 1.5-1: 2.65$ mole ratios, and $\left(-25^{\circ} \mathrm{C}\right)$ for $1: 4$ up to the liquid 1:22 mole ratios.

- Ammonium alum and acetamide in the mole ratio of 1:12 respectively (ASIL) were heated gradually from room temperature to $80{ }^{\circ} \mathrm{C}$ for $10 \mathrm{hrs}$ produced colorless liquid.

2. Ionic liquid preparation with urea:

- Hydrated aluminum nitrate and urea salts in the mole ratio of (1:1.2) respectively (UNIL) were heated gradually from room temperature to $80{ }^{\circ} \mathrm{C}$ for $3 \mathrm{hr}$ producing colorless liquid.

- Ammonium alum and urea salts in the mole ratio of (1:5) respectively (USIL) were also heated gradually from room temperature to $80^{\circ} \mathrm{C}$ for $3 \mathrm{hr}$ producing colorless liquid [9].

A variable density values were observed in the samples under present investigation Table (1). These values were found to be in the range of $1116-1522 \mathrm{~kg} / \mathrm{m}^{3}$ which clearly indicates superiority of these materials over water. Since materials with high density occupy less space and can have a high energy storage capacity [10].

\subsection{Measurements}

Thermal behavior of ionic liquids was investigated using LINSEIS Simultaneous thermal analyzer (STA PT1000), with platinum Evaluation V1.0.89 software. Ionic liquids samples were heated using alumina crucibles under air atmosphere with heating rate of $10^{\circ} \mathrm{C} / \mathrm{min}$ from room temperature up to $500^{\circ} \mathrm{C}$. The instrument was calibrated using melting points of Aluminum, Indium and Lead. The crystallinity and phase identification of samples were determined by X-ray Diffractometer (PAN analytical Philips, X Pert 
PRO MPD PW 3040) employing monochromatized radiation source of $\mathrm{Cu}-\mathrm{Ka}$ of $1.5406{ }^{\circ} \mathrm{A}$. The voltage and current intensities were $8.5 \mathrm{kVA}$. All samples were scanned in the range of 20 to $80^{\circ} 2 \theta$ with a step size of $0.01^{\circ}$ and step time of $0.2 \mathrm{Sec}$ at room temperature $\left(20{ }^{\circ} \mathrm{C}\right)$. FTIR spectra were recorded using PRUKER instrument in the wave number range of $\left(4000-400 \mathrm{~cm}^{-1}\right)$. Conductivity $(\lambda)$ was carried out using HANNA instrument $\mathrm{H} 19811$ in $(\mathrm{mS} / \mathrm{cm})$. Density $(\rho)$ of materials was measured using specific gravity bottle methods at room temperature. Freezing temperatures obtained from a thermometer immersed inside the tube containing $1 \mathrm{ml}$ of ionic liquid stored in deep freezing refrigerator and the temperature was recorded when the sample changed its state.

\section{Results and Discussion}

Thermal characteristics of ionic liquids in present investigation are shown in Table (1). Thermal data of these ionic liquids were obtained from TGA, Fig.(1) and DSC, Fig.(2). A wide range of melting points $\left(-25\right.$ to $\left.50^{\circ} \mathrm{C}\right)$ were observed for different composition of these ionic liquids.

The lowest melting point temperature found for these ionic liquids was $-25^{\circ} \mathrm{C}$ obtained for AN2IL in the mole ratios of (1:4 to $1: 22$ ) while the highest melting points were $50^{\circ} \mathrm{C}$ recorded for aluminum nitrate:acetamide ionic liquid of $1: 1$ mole ratio and $0^{\circ} \mathrm{C}$ for ASIL with 1:12 mole ratio. The highest decomposition onset temperature of $280^{\circ} \mathrm{C}$ was recorded for USIL and lower onset decomposition temperature of $203^{\circ} \mathrm{C}$ was recorded for ASIL. However, thermal temperatures indicated no relation between the melting point and decomposition temperature of these ionic liquids. Yet, it was expected that water would be evolved from these ionic liquids if heated around $100^{\circ} \mathrm{C}$ due to the water percent in starting material of ammonium alum or aluminum nitrate hydrated. But the absence of such evaporation indicated a strong bond of water molecules with the ionic species of ionic liquids as weight loss was only recorded around $203^{\circ} \mathrm{C}$ the lowest onset of decomposition of studied ionic liquids. Such coordination bond was also concluded in other work suggested from UV spectroscopic study of USIL [11]. The ionic liquids stability related to their decomposition temperatures could be arranged in the following order USIL > AN2IL > UNIL $>$ ANIL > ASIL.

Ionic liquid composed of ammonium alum sulfate and urea (USIL) was found to be more stable liquid than ammonium alum with acetamide (ASIL) and other ionic liquids of hydrated aluminum nitrate either with acetamide or urea. This could be arising from stronger interaction of the constituent species of the cationic or anioinic species formed from the original composition salts.

The stability of ionic liquids may be related to the availability of amide groups coordinated with species in the liquid state. It was found that urea containing ionic liquids have more thermal stability than acetamide containing ionic liquids related to the two amide groups present in urea which adding double forces to the liquid. However, the AN2IL which is the second most stable as indicated in the previous arrangement could be related to the high mole ratio of acetamide percent in this liquid (i.e. 1:22) providing more amide molecules to coordinate compared to other ionic liquids, Table (1).

Another chemical property of these ionic liquid was acidity value, from Table (1) RTILs are arranged in the order UNIL > ANIL > AN2IL > ASIL > USIL, which indicates formation of acidic species of lewis form producing ionic species (e.g. for UNIL $\left.\left[\mathrm{Al}\left(\mathrm{NO}_{3}\right)_{2} . \mathrm{n} \mathrm{Urea}\right]^{+} \mathrm{Al}\left(\mathrm{NO}_{3}\right)_{4}^{-}\right)$as analogous type to those reported in aluminum chloride/urea ionic liquid [12] which required additional identification to confirm its identity.

Once the onset temperatures were reached for each ionic liquid Fig.(1) the rate of decomposition of these ionic liquid was found to be very fast producing at the end of the experiments a white powder. 
Table (1)

Thermo-physical properties of ionic liquids (ILs).

\begin{tabular}{|c|c|c|c|c|c|c|c|c|c|}
\hline$I L$ & $\boldsymbol{T}_{m}{ }^{\circ} \mathrm{C}$ & $\boldsymbol{T}_{d}{ }^{\circ} \mathrm{C}$ & $p H$ & $\begin{array}{c}\lambda \\
m S / c m \\
\end{array}$ & $\begin{array}{c}\Delta S \\
\mathrm{~kJ} / \mathrm{kg} \cdot{ }^{\circ} \mathrm{C} \\
\end{array}$ & $\begin{array}{c}\rho \\
\mathrm{kg} / \mathrm{m}^{3} \\
\end{array}$ & $\begin{array}{c}\Delta H \\
k J / k g\end{array}$ & $\begin{array}{c}C_{p} \\
\mathrm{~kJ} / \mathrm{kg} \cdot{ }^{\circ} \mathrm{C} \\
\end{array}$ & $\begin{array}{c}E \mathrm{~kJ} / \mathrm{m}^{3} \\
* 10^{5} \\
\end{array}$ \\
\hline $\begin{array}{l}\text { ASIL } \\
(1: 12)\end{array}$ & 0.0 & 203 & 2.3 & 1.32 & -1.976 & 1116 & -250.51 & 2.1 & 4.758 \\
\hline $\begin{array}{l}\text { USIL } \\
(1: 5) \\
\end{array}$ & -16 & 280 & 4.2 & 4.56 & -16.321 & 1460 & -2434.84 & 2.2 & 9.508 \\
\hline $\begin{array}{l}\text { ANIL } \\
(1: 2.4)\end{array}$ & -20 & 232 & 0.8 & 4.10 & -8.855 & 1405 & -1518.06 & 1.6 & 5.665 \\
\hline $\begin{array}{l}\text { AN2IL } \\
(1: 22)\end{array}$ & -25 & 276 & 1.8 & 3.72 & -17.655 & 1168 & -3697.02 & 2.4 & 8.438 \\
\hline $\begin{array}{l}\text { UNIL } \\
(1: 1.2)\end{array}$ & -20 & 236 & 0.5 & 9.09 & -18.799 & 1522 & -3282.11 & 1.9 & 7.403 \\
\hline
\end{tabular}

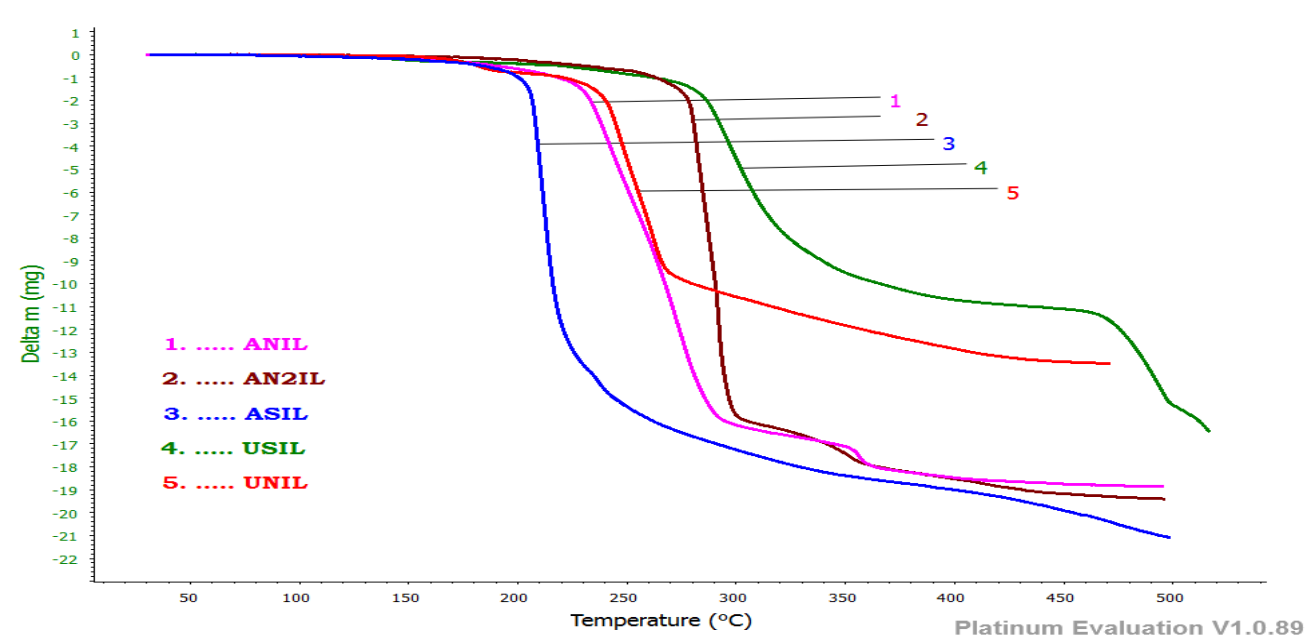

Fig.(1) TGA thermograms of ILs; (1); aluminum nitrate:acetamide, ANIL (1:2.4 mole ratio), (2); aluminum nitrate:acetamide, AN2IL (1:22 mole ratio), (3); ammonium alum:acetamide, ASIL (1:12 mole ratio), (4); ammonium alum:urea, USIL (1:5 mole ratio) and (5); aluminum nitrate: urea, UNIL (1:1.2 mole ratio) all heated from room temperature up to $500{ }^{\circ} \mathrm{C}$.

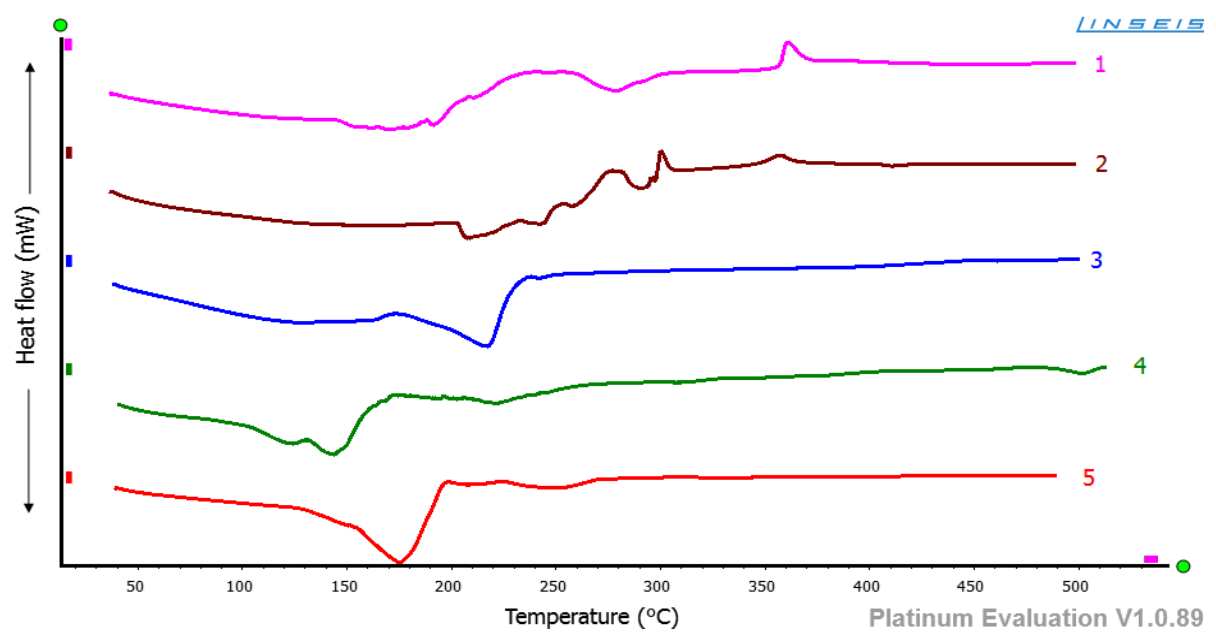

Fig.(2) DSC the rmograms of ILs; (1); aluminum nitrate: acetamide, ANIL (1:2.4 mole ratio), (2); aluminum nitrate: acetamide, AN2IL (1:22 mole ratio), (3); ammonium alum: acetamide, ASIL (1:12 mole ratio), (4); ammonium alum: urea, USIL (1:5 mole ratio) and (5); aluminum nitrate: urea, UNIL (1:1.2 mole ratio) all heated from room temperature up to $500{ }^{\circ} \mathrm{C}$. 
Table (2)

Weight before and after heating of ASIL, USIL, ANIL, AN2IL and UNIL to $500{ }^{\circ} \mathrm{C}$ with their experimental and theoretical weight loss.

\begin{tabular}{|c|c|c|c|c|}
\hline$I L$ & $\begin{array}{c}\text { Wt. of } \\
I L(m g) \\
\end{array}$ & $\begin{array}{l}\text { Wt. of white powder after } \\
\text { heating to } 500{ }^{\circ} \mathrm{C}(\mathrm{mg})\end{array}$ & $\begin{array}{l}\text { Exp. Wt. } \\
\text { loss \% } \\
\end{array}$ & $\begin{array}{c}\text { Theoretical wt loss \% based } \\
\text { on - suggested product }\end{array}$ \\
\hline ASIL & 24.06 & 3.54 & 85.287 & $\mathrm{Al}_{2}\left(\mathrm{SO}_{4}\right)_{3}$ \\
\hline USIL & 24.06 & 7.57 & 68.537 & $\mathrm{NH}_{4} \mathrm{Al}\left(\mathrm{SO}_{4}\right)_{2}$ \\
\hline ANIL & 24.02 & 5.15 & 78.560 & $78.707-\mathrm{Al}_{2} \mathrm{O}_{3}+\mathrm{NH}_{2} \mathrm{COCH}_{3}$ \\
\hline AN2IL & 24.22 & 4.88 & 79.851 & $79.319-\mathrm{Al}_{2} \mathrm{O}_{3}+5 \mathrm{NH}_{2} \mathrm{COCH}_{3}$ \\
\hline UNIL & 23.84 & 10.35 & 56.586 & $\begin{array}{lll}56.577- & \mathrm{Al}\left(\mathrm{NO}_{3}\right)_{3}+\mathrm{Al}_{2} \mathrm{O}_{3} \\
\end{array}$ \\
\hline
\end{tabular}

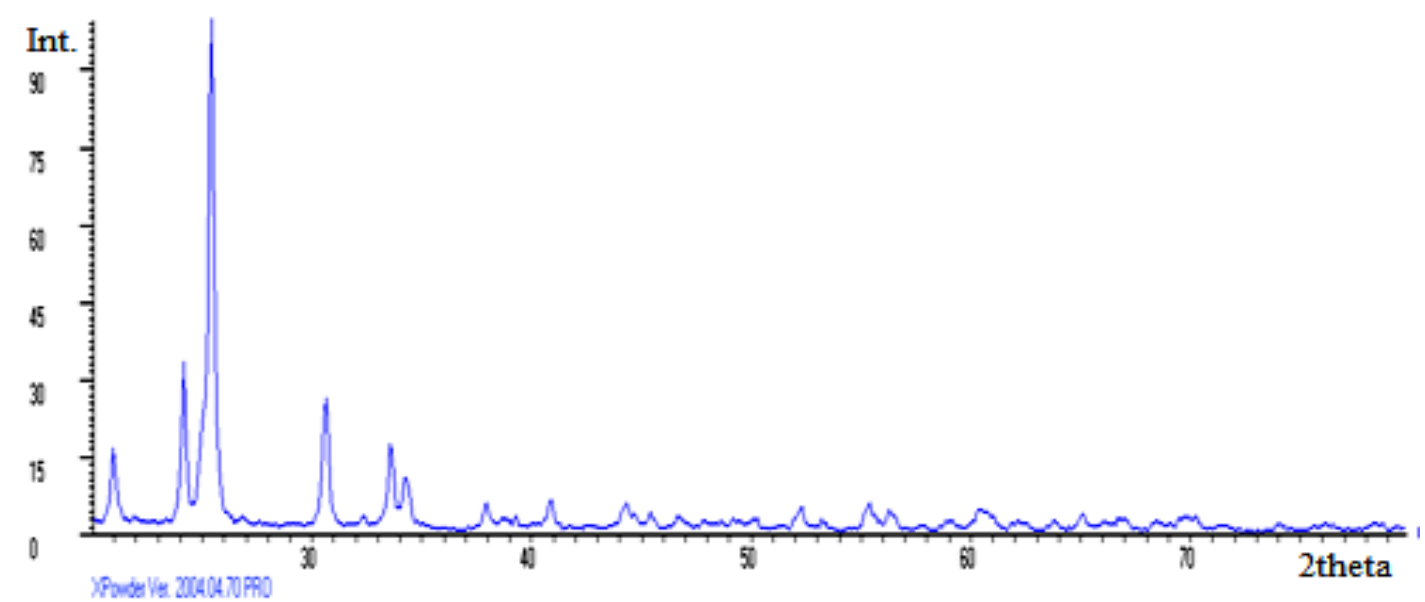

Fig.(3) X-ray diffraction of hydrated ammonium aluminum sulfate: acetamide room temperature ionic liquid in mole ratio (1:12) after heating it up to $500{ }^{\circ} \mathrm{C}$.

Table (3)

$X$-ray data of the residue of heating hydrated ammonium aluminum sulfate: acetamide (1:12 mole ratio) to $500{ }^{\circ} \mathrm{C}$ compared with $\mathrm{Al}_{2}\left(\mathrm{SO}_{4}\right)_{3}[13]$.

\begin{tabular}{|c|c|c|c|c|}
\hline $2 \theta$ (measured) & $\begin{array}{c}2 \theta \\
\text { (reference) }\end{array}$ & $\begin{array}{c}\text { Intensity } \\
\text { (measured) }\end{array}$ & $\begin{array}{c}\text { Intensity } \\
\mathrm{Al}_{2}\left(\mathrm{SO}_{4}\right)_{3}(\text { Reference }) \\
\end{array}$ & $\begin{array}{c}\text { Miller indices } \\
\quad \mathrm{h} \mathrm{l}\end{array}$ \\
\hline 20.969 & 20.934 & 17 & 20 & 104 \\
\hline 24.181 & 24.780 & 34 & 20 & 2006 \\
\hline 25.437 & 25.427 & $\overline{\mid l 100}$ & $\overline{\mid 100}$ & $\begin{array}{lll}113 \\
\end{array}$ \\
\hline 30.603 & 30.644 & 26 & 17 & 024 \\
\hline 33.535 & 33.497 & 18 & 18 & 116 \\
\hline 33.675 & - & 16 & - & \\
\hline 34.233 & 34.222 & $\overline{11}$ & $\overline{10}$ & 211 \\
\hline 34.373 & 35.036 & $\overline{11}$ & 2 & 122 \\
\hline
\end{tabular}

The final decomposition products resulted from heating these ionic liquids to $500^{\circ} \mathrm{C}$ were analyzed by X-ray diffraction and FTIR spectroscopy to identify the remaining white powder, the results are summarized in Table (2).

The white powder remained from decomposition of ASIL was examined by X-ray Fig.(3) and FTIR and found to be pure crystalline rhombohedral aluminum sulfate with crystallite size of $48.151 \mathrm{~nm}$ calculated from Scherer equation [14]:

$$
D=k * \lambda / \beta * \cos \theta
$$

where $\mathrm{k}$ is a constant $\sim 0.9, \lambda$ is the wave length of $\mathrm{X}$-ray $\left(1.5406 \mathrm{~A}^{\circ}, \beta\right.$ is the full width of diffraction peak at half maximum (FWHM) intensity, 0.2952 and $\theta$ is the Bragg angle,(25.437/2). The calculated crystallite size of aluminum sulfate agree with other report [14]. 




Fig.(4) FTIR of hydrated ammonium aluminum sulfate: acetamide room temperature ionic liquid in mole ratio (1:12) in black color, and in red color after heating it up to $500{ }^{\circ} \mathrm{C}$.

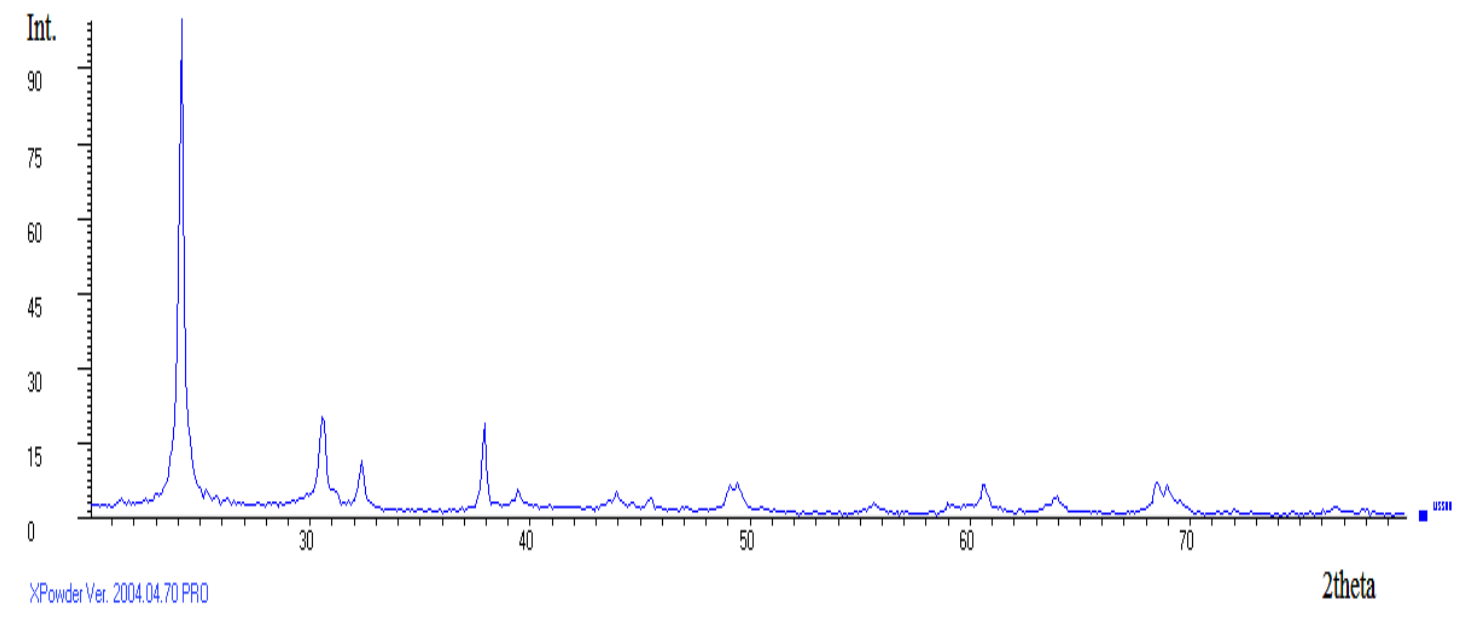

Fig.(5) X-Ray diffraction of hydrated ammonium aluminum sulfate: urea room temperature ionic liquid in mole ratio (1:5) after heating up to $500^{\circ} \mathrm{C}$.

Table (4)

$X$-ray data of hydrated ammonium aluminum sulfate: urea (1:5 mole ratio) residue after heating to $500^{\circ} \mathrm{C}$ compared with $\mathrm{NH}_{4} \mathrm{Al}\left(\mathrm{SO}_{4}\right)_{2}[15]$.

\begin{tabular}{|c|c|c|c|c|}
\hline $\begin{array}{c}2 \theta \\
\text { (measured) }\end{array}$ & $\begin{array}{c}2 \theta \\
\text { (reference) }\end{array}$ & $\begin{array}{c}\text { Intensity } \\
\text { (measured) }\end{array}$ & $\begin{array}{c}\text { Intensity } \\
\mathrm{NH}_{4} \mathrm{Al}\left(\mathrm{SO}_{4}\right)_{2} \\
(\text { reference }) \\
\end{array}$ & $\begin{array}{c}\text { Miller indices } \\
\qquad k \boldsymbol{l}\end{array}$ \\
\hline 21.435 & 21.435 & 4 & 4 & 002 \\
\hline 24.134 & 24.111 & 100 & 100 & 101 \\
\hline 25.251 & - & 6 & - & \\
\hline 30.557 & 30.591 & 20 & 28 & 102 \\
\hline 30.650 & - & 19 & - & \\
\hline 32.325 & 32.375 & 15 & 12 & 003 \\
\hline 37.957 & 37.833 & 19 & 15 & 110 \\
\hline
\end{tabular}


The vibrational frequencies of the white powder after heating ASIL to $500^{\circ} \mathrm{C}$, (Fig.4) indicated disappearance of amide and hydroxyl group bands with increased intensities of bands belong to sulfate $\left(\mathrm{SO}_{4}{ }^{-2}\right)$ stretching vibration at $1178.32 \mathrm{~cm}^{-1}[16]$ and aluminum-oxide Al-O stretching vibrations at 497.58 to $678.78 \mathrm{~cm}^{-1}[14]$. This could be taken as further prove to the decomposition of ASIL producing aluminum sulfate $\mathrm{Al}_{2}\left(\mathrm{SO}_{4}\right)_{3}$.

The recorded weight of ASIL final product from TGA/DTG was (14.71\%) agreed with calculated weight percent of $(14.73 \%)$ calculated on the base of sample weight of ionic liquid if completely decomposed to $\mathrm{Al}_{2}\left(\mathrm{SO}_{4}\right)_{3}$ supported the predicted final formation of aluminum sulfate in X-ray diffraction and FTIR spectroscopy measurements. The following equation (4) could be resulted from the decomposition of ASIL proposed with the aid of thermal decomposition of acetamide reported up to $545^{\circ} \mathrm{C}$ as follow[17]:

\section{$2 \mathrm{CH}_{3} \mathrm{CONH}_{2} \rightarrow \mathrm{CH}_{3} \mathrm{COOH}+\mathrm{NH}_{3}+\mathrm{CH}_{3} \mathrm{CN}$}

and thermal decomposition of ammonium alum up to 500 as follow[18]:

$$
\begin{aligned}
& 3 \mathrm{NH}_{4} \mathrm{Al}\left(\mathrm{SO}_{4}\right)_{2} .12 \mathrm{H}_{2} \mathrm{O}_{(\mathrm{s})} \rightarrow \mathrm{NH}_{4} \mathrm{Al}\left(\mathrm{SO}_{4}\right)_{2(\mathrm{~s})}+ \\
& \mathrm{Al}_{2}\left(\mathrm{SO}_{4}\right)_{3(\mathrm{~s})}+37 \mathrm{H}_{2} \mathrm{O}_{(\mathrm{g})}+2 \mathrm{NH}_{3(\mathrm{~g})}+\mathrm{SO}_{3(\mathrm{~g})}
\end{aligned}
$$

$\mathrm{NH}_{4} \mathrm{Al}\left(\mathrm{SO}_{4}\right)_{2} .12 \mathrm{H}_{2} \mathrm{O} / 12 \mathrm{NH}_{2} \mathrm{COCH}_{3} \rightarrow 12.5 \mathrm{H}_{2}$ $\mathrm{O}_{(\mathrm{g})}+7 \mathrm{NH}_{3(\mathrm{~g})}+6 \mathrm{CH}_{3} \mathrm{COOH}_{(\mathrm{g})}+0.5 \mathrm{SO}_{3(\mathrm{~g})}+6 \mathrm{CH}_{3}$ $\mathrm{CN}_{(\mathrm{g})}+0.5 \mathrm{Al}_{2}\left(\mathrm{SO}_{4}\right)_{3(\mathrm{~s})}$

In similar examination procedure, the final white powder obtained from the decomposition of USIL was also examined by X-ray diffraction (Fig.(5) and Table (4)) and it was found to have similar diffraction data to hexagonal $\mathrm{NH}_{4} \mathrm{Al}\left(\mathrm{SO}_{4}\right)_{2}$ with crystalline size of $36.023 \mathrm{~nm}$ calculated from equation(1) with the full width of diffraction peak at half maximum (FWHM) intensity, $\beta=0.3936$ and $2 \theta$ of $24.134 / 2$.

However, FTIR vibrational bands indicated again, the intense sulfate vibrational frequency at maximum of $1171.17 \mathrm{~cm}^{-1}$ and Al-O stretching at $410.07-682.16 \mathrm{~cm}^{-1}$ with less intense amine vibrational bands at $1647.05 \mathrm{~cm}^{-1}$, in contrast to the completely disappearance of latter frequency in the white powder of final decomposition of ASIL.

The recorded weight obtained from TGA/DTG of USIL final product was found to be $31.46 \%$ which agreed with calculated weight percent of $31.47 \%$ based on the formation of $\mathrm{NH}_{4} \mathrm{Al}\left(\mathrm{SO}_{4}\right)_{2}$ as final product from USIL decomposition at $500^{\circ} \mathrm{C}$ which the supports the results of $\mathrm{X}$-ray diffraction and FTIR spectroscopic measurements. The following equation (5) was suggested according to these results and based on the decomposition of both ammonium alum as stated earlier and urea which leads to HNCO and $\mathrm{NH}_{3}$ above its melting temperature to $360^{\circ} \mathrm{C}[19,20]$ :

$\mathrm{NH}_{4} \mathrm{Al}\left(\mathrm{SO}_{4}\right)_{2} .12 \mathrm{H}_{2} \mathrm{O} / 5 \mathrm{CO}\left(\mathrm{NH}_{2}\right)_{2(1)} \rightarrow 12 \mathrm{H}_{2} \mathrm{O}_{(\mathrm{g})}$ $+5 \mathrm{NH}_{3(\mathrm{~g})}+5 \mathrm{HCNO}_{(\mathrm{g})}+\mathrm{NH}_{4} \mathrm{Al}_{2}\left(\mathrm{SO}_{4}\right)_{2(\mathrm{~s})}$

The X-Ray diffraction of final decomposition products of ANIL and UNIL showed an amorphous crystalline structure Fig.(7) consisting only few broad maxima[21].

The FTIR spectra for final decomposition product of ANIL, Fig.(9) showed the disappearance of amide and hydroxyl groups with small stretching vibration band at $1535.70 \mathrm{~cm}^{-1}$ that might be referred to the presence of carbonyl group of acetamide with shifting to higher stretching vibration band at $1653.80 \mathrm{~cm}^{-1}$ before heating ANIL to $500^{\circ} \mathrm{C}$.

The stretching vibration bands at 556.28 to $771.25 \mathrm{~cm}^{-1}$ was related to aluminum-oxide.

The FTIR of final product of heating AN2IL, Fig.(10) gave different bands than that of ANIL. In general, most bands before and after heating AN2IL remained with lower intensities. The stretching vibration bands at 2800-3500 $\mathrm{cm}^{-1}$ in which amine group has 2-peaks (3000 and 3400) $\mathrm{cm}^{-1}$ and methyl group $(\mathrm{C}-\mathrm{H})$ bellow $3000 \mathrm{~cm}^{-1}$ that appeared to be overlapped which might be resulted from both methyl and amine groups of the acetamide. With more intense stretching vibration bands at $2361.09 \mathrm{~cm}^{-1}$ and $2121.92 \mathrm{~cm}^{-1}$ that may be belong to $(\mathrm{C} \equiv \mathrm{N})$ bond of acetamide. The bands of around $1600 \mathrm{~cm}^{-1}$ could be attributed to carbonyl of acetamide and the broad stretching vibration band in the range 870.46-454.09 $\mathrm{cm}^{-1}$ refer to (Al-O) while bands at 1385.61 and 
$1334.72 \mathrm{~cm}^{-1}$ related to nitrate group were disappeared. The vibrational frequencies of nitrate group at $1385.61 \mathrm{~cm}^{-1}$ and $1334.72 \mathrm{~cm}^{-1}$ of ANIL and AN2IL was also completely disappeared when they heated to $500^{\circ} \mathrm{C}$.

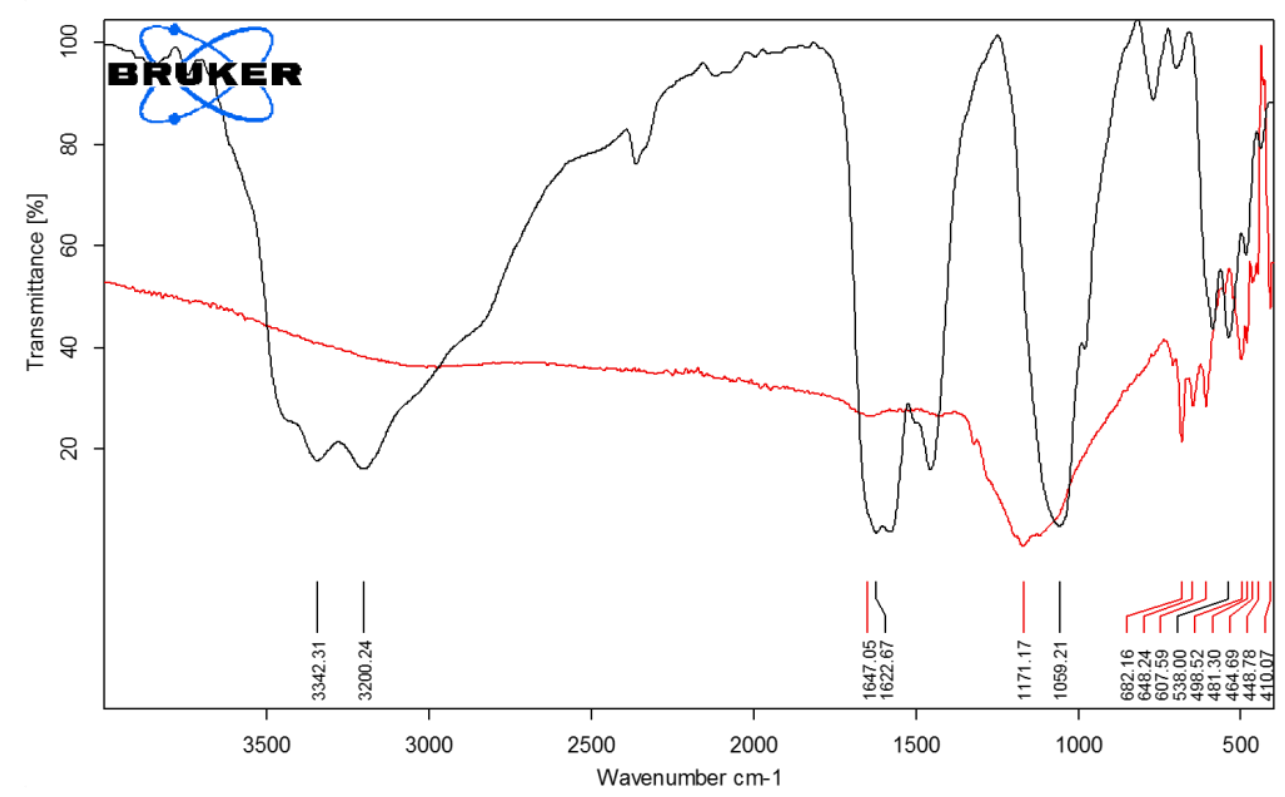

Fig.(6) FTIR of hydrated ammonium aluminum sulfate: urea room temperature ionic liquid in mole ratio (1:5) after heating up to $500^{\circ} \mathrm{C}$.

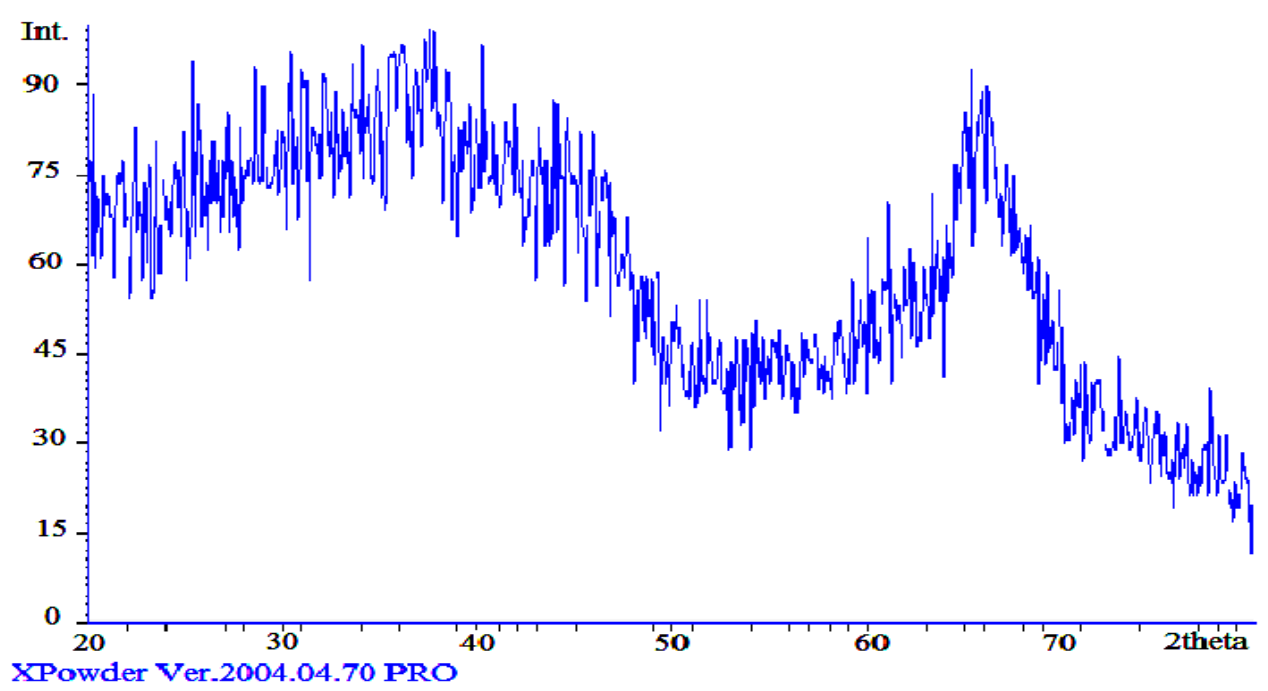

Fig.(7) X-ray diffraction of the product remaining from heating hydrated aluminum nitrate: acetamide, ANIL in mole ratio (1:2.4) up to $500{ }^{\circ} \mathrm{C}$.

Thermal decomposition of pure aluminum nitrate [18]:

$\mathrm{Al}\left(\mathrm{NO}_{3}\right)_{3} \cdot 9 \mathrm{H}_{2} \mathrm{O} \rightarrow$ amorphous- $\mathrm{Al}_{2} \mathrm{O}_{3}$ at $(200-$ 700) ${ }^{\circ} \mathrm{C}$

This equation could help to suggest thermal decomposition of ANIL and AN2IL. The obtained weight of final products of heating ANIL and AN2IL were $21.44 \%$ and $20.15 \%$ respectively which were close to those calculated from heating the liquids $21.30 \%$ and $20.68 \%$ which are based on equation (7) and (8) respectively:

$\mathrm{Al}\left(\mathrm{NO}_{3}\right)_{3} .9 \mathrm{H}_{2} \mathrm{O} / 2.4 \mathrm{NH}_{2} \mathrm{COCH}_{3(\mathrm{l})} \rightarrow 9 \mathrm{H}_{2} \mathrm{O}_{(\mathrm{g})}+2$ $\mathrm{NO}_{2(\mathrm{~g})}+\mathrm{NO}_{(\mathrm{g})}+1.25 \mathrm{O}_{2(\mathrm{~g})}+0.7 \mathrm{CH}_{3} \mathrm{COOH}_{(\mathrm{g})}+0.7$

$\mathrm{CH}_{3} \mathrm{CN}_{(\mathrm{g})}+0.7 \mathrm{NH}_{3(\mathrm{~g})}+\mathrm{am}-\mathrm{Al}_{2} \mathrm{O}_{3(\mathrm{~s})}+$ $\mathrm{NH}_{2} \mathrm{COCH}_{3}$ (s) 
$\mathrm{Al}\left(\mathrm{NO}_{3}\right)_{3} .9 \mathrm{H}_{2} \mathrm{O} / 22 \mathrm{NH}_{2} \mathrm{COCH}_{3(\mathrm{l})} \rightarrow 9 \mathrm{H}_{2} \mathrm{O}_{(\mathrm{g})}+2$

$\mathrm{NO}_{2(\mathrm{~g})}+\mathrm{NO}_{(\mathrm{g})}+1.25 \mathrm{O}_{2(\mathrm{~g})}+8.5 \mathrm{CH}_{3} \mathrm{COOH}_{(\mathrm{g})}$

$+8.5 \mathrm{NH}_{3(\mathrm{~g})}+8.5 \mathrm{CH}_{3} \mathrm{CN}_{(\mathrm{g})}+\quad \mathrm{am}-\mathrm{Al}_{2} \mathrm{O}_{3(\mathrm{~s})}+$

$5 \mathrm{NH}_{2} \mathrm{COCH}_{3(\mathrm{~s})}$

The FTIR spectra for final decomposition product of UNIL, Fig.(8) show one broad band from $3819.41 \mathrm{~cm}^{-1}$ to $821.95 \mathrm{~cm}^{-1}$ compared to original UNIL Fig.(8). The recorded weight obtained from TGA/DTG $(43.41 \%)$ agreed with calculated weight percent of $(43.423 \%)$ based on equation (9):
$\mathrm{Al}\left(\mathrm{NO}_{3}\right)_{3} .9 \mathrm{H}_{2} \mathrm{O} / 1.2 \mathrm{CO}\left(\mathrm{NH}_{2}\right)_{2(1)} \rightarrow 9 \mathrm{H}_{2} \mathrm{O}_{(\mathrm{g})}+1.2$ $\mathrm{NH}_{3(\mathrm{~g})}+1.2 \mathrm{HCNO}_{(\mathrm{g})}+0.41 \mathrm{NO}_{2(\mathrm{~g})}+$ a mixture $\mathrm{Al}\left(\mathrm{NO}_{3}\right)_{3}+\mathrm{am}-\mathrm{Al}_{2} \mathrm{O}_{3}$

The presence of acetamide in the final product after heating ANIL and AN2IL could be due to non eutectic ionic liquids and hence the excess acetamide present was not completely decomposed at $500^{\circ} \mathrm{C}$ as the reported temperature of complete decomposition of acetamide was to be in $545^{\circ} \mathrm{C}[17]$.

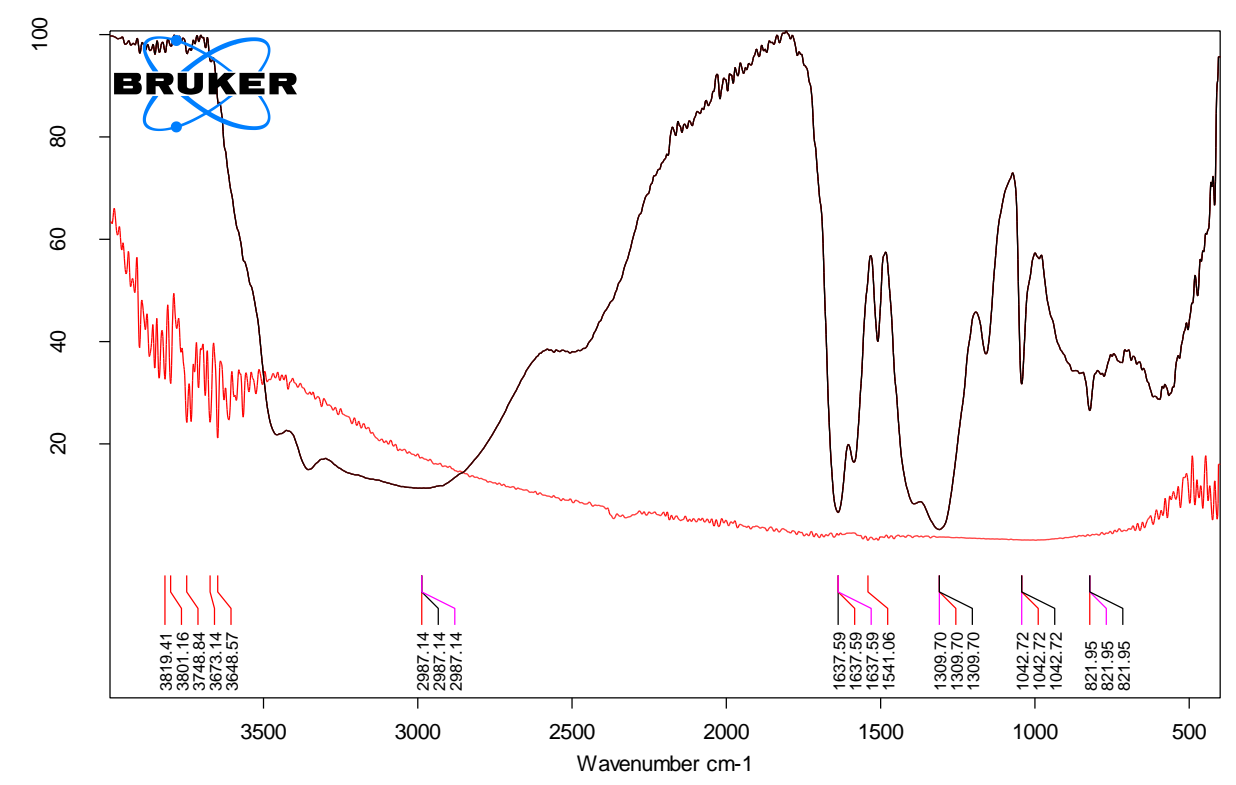

Fig.(8) FTIR of hydrated aluminum nitrate: urea, UNIL in mole ratio (1:1.2) in black color and in red color after heating up to $500^{\circ} \mathrm{C}$.

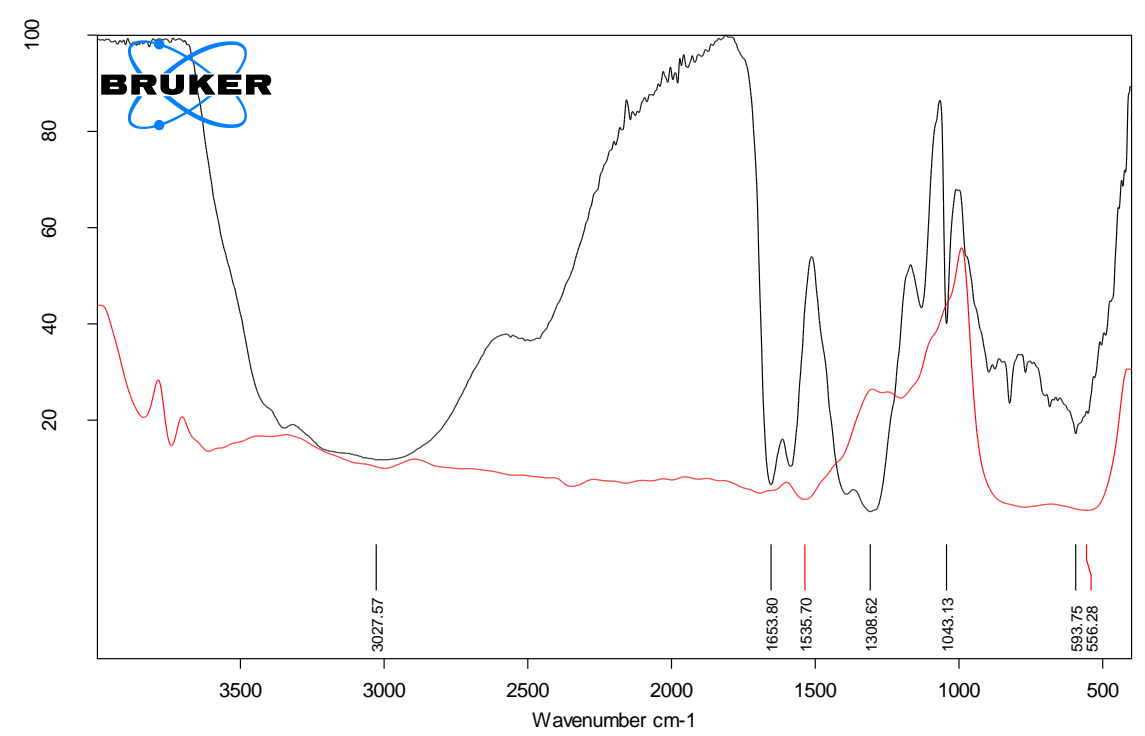

Fig.(9) FTIR of hydrated aluminum nitrate: acetamide, ANIL in mole ratio (1:2.4) in black color, and in red color after heating it up to $500^{\circ} \mathrm{C}$. 


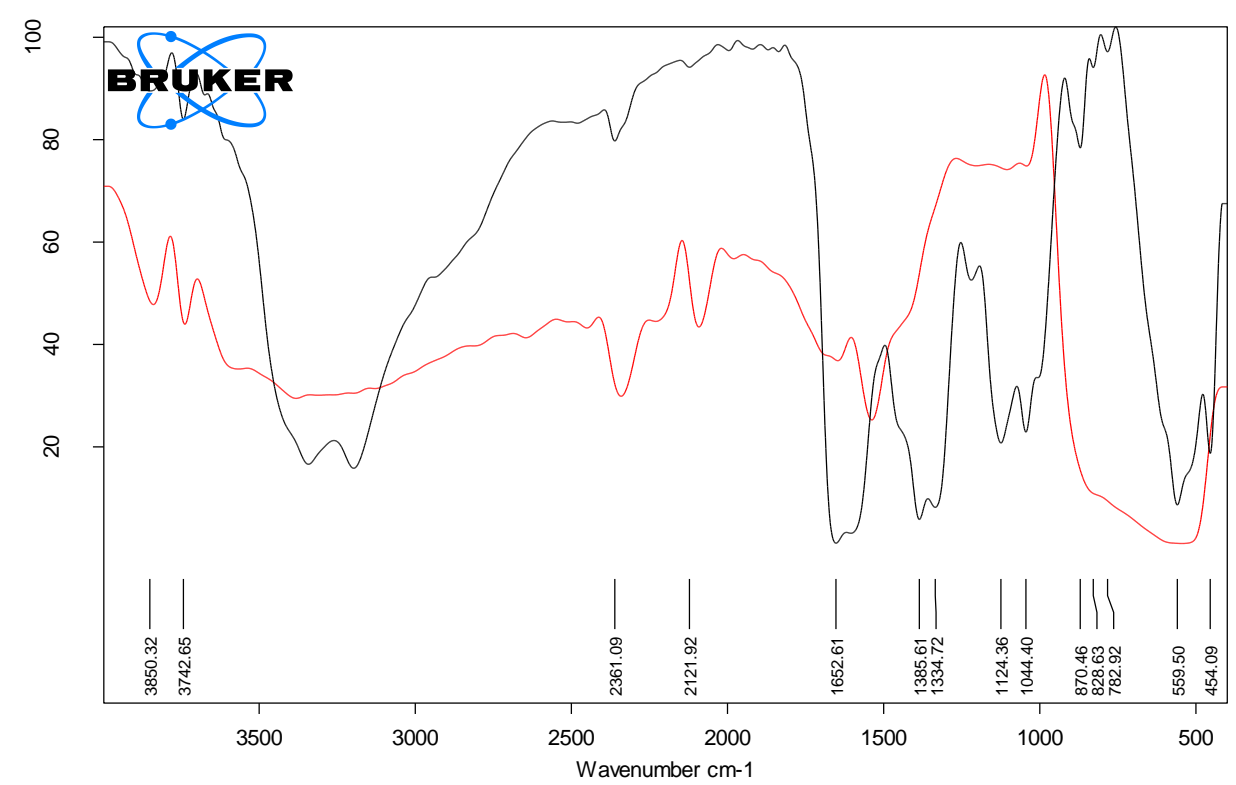

Fig.(10) FTIR of hydrated aluminum nitrate: acetamide room temperature ionic liquid in mole ratio (1:22) in black color and in red color after heating it up to $500{ }^{\circ} \mathrm{C}$.

\subsection{Conductivity}

Conductivities of these ionic liquids were found to have no relation with their $\mathrm{pH}$ values as the smaller $\mathrm{pH}$ value did not necessarily give higher conductivity, Table (1). UNIL showed much higher conductivity than other ionic liquids while acetamide ionic liquids show lower conductivity than urea ionic liquids. Moreover the presence of much higher mole ratio of acetamide of 22 in AN2IL did not show appreciable increase in conductivity. The low conductivity values of ionic liquids agreed with other reported ionic liquids which was related to the hindrance of ionic mobility [22].
The highest conductivity found was $\left(9.09 \mathrm{mS.cm}{ }^{-1}\right)$ for UNIL at $26^{\circ} \mathrm{C}$ and reached $12.5{\mathrm{mS} . \mathrm{cm}^{-1}}^{-1}$ at $75{ }^{\circ} \mathrm{C}$ as shown in Fig.(11). Other ionic liquids have lower conductivities $\left(4.56 \mathrm{mS} . \mathrm{cm}^{-1}\right.$ at $26{ }^{\circ} \mathrm{C}$ and $1.32 \mathrm{mS} . \mathrm{cm}^{-1}$ at $31{ }^{\circ} \mathrm{C}$ for USIL and ASIL respectively. The lowest conductivity value from these ionic liquids was much higher than some ionic liquids, e.g. $\left[\mathrm{C}_{2} \mathrm{MIm}\right][$ amino acids]

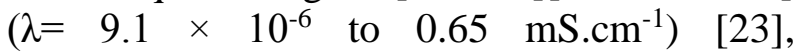
[N2222][pro] $\left(0.46 \mathrm{mS} . \mathrm{cm}^{-1}\right)$ and $\left[\mathrm{N}_{2222}\right][\mathrm{ser}]$ $\left(0.16 \mathrm{mS} . \mathrm{cm}^{-1}\right)$ [24]. The conductivity of these ionic liquids was found to be directly proportional with temperature, Fig.(1).

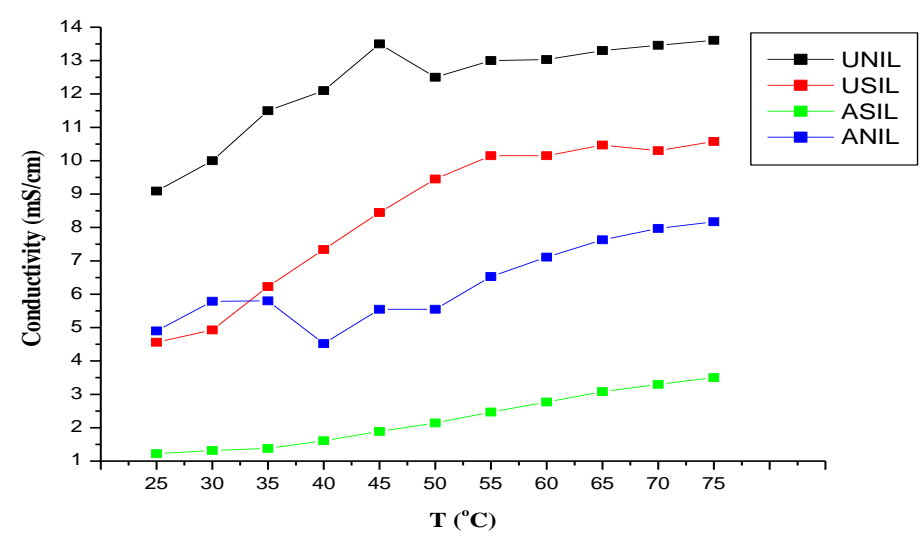

Fig.(11) Conductivity (mS.cm-1) of (a): UNIL mole ratio (1:1.2), (b): USIL mole ratio (1:5), (c): ASIL mole ratio (1:12) and (d): ANIL in mole ratio (1:2.4) versus temperature up to $70^{\circ} \mathrm{C}$. 
Table (5)

A comparison of heat capacities $\left(C_{p}\right)$, densities $(\rho)$, temperature range $\left({ }^{\circ} C\right)$ and thermal energy storage capacities $(E)$ of some heat storage materials.

\begin{tabular}{|c|c|c|c|c|c|}
\hline $\begin{array}{c}\text { Heat storage } \\
\text { materials }\end{array}$ & $\begin{array}{c}C_{p} \\
\left(\mathrm{~kJ} / \mathrm{kg} .{ }^{\circ} \mathrm{C}\right) \\
\end{array}$ & $\begin{array}{c}\rho \\
\left(\mathrm{kg} / \mathrm{m}^{3}\right) \\
\end{array}$ & $\begin{array}{c}\text { Temperature } \\
\text { range }\left({ }^{\circ} \mathrm{C}\right)\end{array}$ & $\begin{array}{c}E \\
\left(\mathrm{~kJ} / \mathrm{m}^{3}\right)^{*} * 10^{5} \\
\end{array}$ & $\operatorname{Ref}$. \\
\hline Water & 1.6 at $100^{\circ} \mathrm{C}$ & 1000 & $0-100$ & $1.600 *$ & [6] \\
\hline Therminol VP-1 & 1.78 at $130^{\circ} \mathrm{C}$ & 1060 & - & 1.887 & [25] \\
\hline $\begin{array}{l}\text { Molten salt } \\
\text { Nitrate salts } \\
\end{array}$ & 1.45 at $300^{\circ} \mathrm{C}$ & 1992 & $220-500$ & $10.976^{*}$ & [26] \\
\hline$\left[\mathrm{C}_{2} \mathrm{MIm}\right]\left[\mathrm{BF}_{4}\right] \mathrm{IL}$ & 1.28 at $130^{\circ} \mathrm{C}$ & 1253 & - & 1.609 & [25] \\
\hline$\left[\mathrm{C}_{4} \mathrm{MIm}\right]\left[\mathrm{BF}_{4}\right] \mathrm{IL}$ & 1.66 at $130^{\circ} \mathrm{C}$ & 1175 & - & 1.949 & [25] \\
\hline $\mathrm{C}_{16} \mathrm{CPTS}$ IL & 2.85 at $145^{\circ} \mathrm{C}$ & 922 & - & 2.628 & [25] \\
\hline$\left[\mathrm{C}_{8} \mathrm{MIm}\right]\left[\mathrm{PF}_{6}\right] \mathrm{IL}$ & 2.5 & 1400 & $-75-416$ & $17.185^{*}$ & [6] \\
\hline$\left[\mathrm{N}^{+} 2222\right]\left[\mathrm{IO}_{3}^{-}\right] \mathrm{IL}$ & 1.7 & 1162 & $53-180$ & 2.293 & [5] \\
\hline$\left[\mathrm{N}^{+}{ }_{4444}\right]\left[\mathrm{BF}_{4}{ }^{-}\right] \mathrm{IL}$ & 1.0 & 1291 & $71-$ & 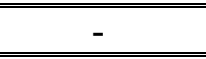 & [27] \\
\hline$\left[\mathrm{N}^{+}{ }_{4444}\right]\left[\mathrm{PF}_{6}{ }^{-}\right] \mathrm{IL}$ & 0.4 & 1234 & $71-$ & - & [27] \\
\hline$\left[\mathrm{N}^{+}{ }_{4444}\right]\left[\mathrm{NO}_{3}{ }^{-}\right] \mathrm{IL}$ & 1.5 & 1195 & $98-$ & - & [27] \\
\hline ANIL(1:2.4) & 1.6 & 1405 & $-20-232$ & 5.665 & This work \\
\hline AN2IL(1:22) & 2.4 & 1168 & $-25-276$ & 8.438 & This work \\
\hline ASIL(1:12) & 2.1 & 1116 & $0-203$ & 4.758 & This work \\
\hline USIL(1:5) & 2.2 & 1460 & $-16-280$ & 9.508 & $\begin{array}{l}\text { This work } \\
\end{array}$ \\
\hline UNIL(1:1.2) & 1.9 & 1522 & $-20-236$ & 7.403 & This work \\
\hline
\end{tabular}

\subsection{Heat capacity $(\mathrm{Cp})$ and thermal energy storage capacity $(\mathrm{E})$ :}

Heat capacities of all ILs were elucidated from DSC thermograms, Fig.(2) using $\mathrm{Al}_{2} \mathrm{O}_{3}$ as reference material. Thermal energy storage capacities were calculated in the usable temperature range $\left(T_{\mathrm{d}}-T_{\mathrm{m}}\right)$ using the following equation [5]:

$$
\mathrm{E}=\rho \cdot \mathrm{Cp}\left(\mathrm{T}_{\mathrm{d}}-\mathrm{T}_{\mathrm{m}}\right)
$$

The value of heat capacity is not considered to be significant in the selection of ionic liquid as heat storage media [5] as the most important property of thermal energy storage capacity depends on temperature range and density.

Thermal energy storage capacity of AN2IL, USIL and USIL were found to have relatively close values but larger by (1.5-2 times) than those of ASIL and ANIL, Table (1). Most of ILs showed a significantly higher value of thermal energy storage capacity in the diversity of 4.758 to $9.508 \times 10^{5} \mathrm{~kJ} / \mathrm{m}^{3}$.

The heat capacities $(C p)$, densities $(\rho)$, and thermal energy storage capacities $(E)$ of some heat storage materials are listed in Table (5), including water, Therminol VP-1, nitrate salts and some ionic liquids.

Thermal energy storage capacity (E) of ionic liquids obtained in this work (4.758 to $9.508 \times 10^{5} \mathrm{~kJ} / \mathrm{m}^{3}$ ) were larger than many heat storage material presented in Table (5); e.g. $\left[\mathrm{N}^{+}{ }_{2222}\right]\left[\mathrm{IO}_{3}{ }^{-}\right]$and $\left[\mathrm{N}^{+}{ }_{4444}\right]\left[\mathrm{BF}_{4}{ }^{-}\right]$except molten nitrate salts and $\left[\mathrm{C}_{8} \mathrm{MIm}\right]\left[\mathrm{PF}_{6}\right]$ ionic liquid. High freezing points of $120^{\circ} \mathrm{C}$ of nitrate salts restrict their usage as heat storage and transfer fluid that add complexity of design, operation and maintenance of a trough plant and ionic liquids containing $\mathrm{PF}_{6}{ }^{-}$ions are hydrolytically unstable, have the liability to decompose and produce $\mathrm{HPO}_{2} \mathrm{~F}_{2}, \mathrm{H}_{2} \mathrm{PO}_{3} \mathrm{~F}, \mathrm{H}_{3} \mathrm{PO}_{4}$, and highly corrosive HF [28].

Also it was found that the lowest value of heat capacity of ionic liquids presented in this work was higher than some ionic liquids i.e $\left[\mathrm{N}^{+}{ }_{4444}\right]\left[\mathrm{BF}_{4}^{-}\right],\left[\mathrm{N}^{+}{ }_{4444}\right]\left[\mathrm{PF}_{6}{ }^{-}\right]$ and $\left[\mathrm{N}^{+}{ }_{4444}\right]\left[\mathrm{NO}_{3}{ }^{-}\right]$, Table(5). Moreover, the studied ionic liquids have some interesting and favorable properties, such as the higher enthalpies, higher specific heat capacities and higher thermal energy storage capacity. In addition, ammonium alum or aluminum nitrate based RTILs could be considered safer than other ionic liquids $\left\{\left[\mathrm{C}_{4} \mathrm{MIm}\right]\left[\mathrm{BF}_{4}\right]\right.$ and 
$\left.\left[\mathrm{C}_{8} \mathrm{MIm}\right]\left[\mathrm{PF}_{6}\right]\right\}$ which are liable to release high toxic and corrosive product (HF) [29]. On basis of safety, moisture stability and lower cost, these ionic liquids have the advantageous for usage in thermal applications such as thermal storage media.

\section{Conclusions}

Ionic liquids deserve a consideration to be valuable candidate to the traditional materials used as thermal energy storage. These RTILs have unique properties of storing and releasing a significant amount of thermal energy with non volatile properties. Ionic liquids under the present study of hydrated ammonium aluminum sulfate:urea and hydrated aluminum nitrate: acetamide in the mole ratio (1:22) offer thermal stability (up to $280^{\circ} \mathrm{C}$ and $276^{\circ} \mathrm{C}$ respectively) and working temperature (down to $-16^{\circ} \mathrm{C}$ to $-25^{\circ} \mathrm{C}$ ) in addition to the high storage capacity $\left(9.508 * 10^{5} \mathrm{~kJ} / \mathrm{m}^{3}\right)$.

\section{References}

[1] Thirugnanam C. and Marimuthu P., "Experimental Analysis of Latent Heat Thermal Energy Storage using Paraffin Wax as Phase Change Material", Int. J. Engineering and Innovative Technology (IJEIT), 3(2), 372-376, 2013.

[2] Ali K., Ahmed S. and Kamil, "Thermal Properties and Thermal Reliability of Capric Acid/Stearic Acid Mixture for Latent Heat Thermal Energy Storage", J. Energy Sources, Part A: Recovery, Utilization and Environmental Effects, 31, 199-207, 2009.

[3] Vasishta D. Bhatt, Kuldip G. and Arunabh M.; "Thermal Energy Storage Capacity of some Phase changing Materials and Ionic Liquids", Int. J. Chem. Technol., 2(3), 1771-1779, 2010.

[4] T. Scmidt, D. Mangold, and H. MüllerSteinhagen "Central Solar heating Plants with Seasonal Storage in Germany", $J$. Solar Energy,76(1-3),165-174, 2004.

[5] Vasishta D. Bhatt and Kuldip G.; "Ion Exchange Synthesis and Thermal Characteristics of some $\left[\mathrm{N}^{+}{ }_{2222}\right]$ Based Ionic Liquids", J. Bull. Mater. Sci., 36(6), $1121-$ 1125, 2013.

[6] Banqiu W., Ramana G. Reddy and Robin D. Rogers; "Novel Ionic Liquid Thermal
Storage for Solar Thermal Electric Power Systems", J. Proceedings of Solar Forum, 445-451, 2001.

[7] Dincer I. and Rosen M. A.; "Thermal Energy Storage, Systems and Applications", Chichester, England: John Wiley \& Sons, 2002.

[8] Yan S., Danielle F. Kennedy, Tamar L. Greaves, Asoka W., Roger J. Mulder, Niqel K., Gonghua S. and Calum J. Drummond, "Protic Ionic Liquids with Fluorous Anions Physicochemical Properties and SelfAssembly Nanostructure", J. Phys. Chem. Chem. Phys., 14(22), 7981-7992, 2012.

[9] Hadi M. A. Abood, "New Ionic Liquid made from Hydrated Aluminum Sulfate with Amide", Patent, Central Organization for Standardization and Quality, Property division, Application no. 336, Iraq, 2011.

[10] Zhang Y., Jiang Y. and Jiang Y.; "A Simple Method, The T-History Method, of determining The Heat of Fusion, Specific Heat And Thermal Conductivity of PhaseChange Materials", J. Sci. Technol. 10, 201, 1999.

[11] Zena N. Al-Qudsi and Hadi M. A. Abood, "The Electronic Transition Behavior $\mathrm{Cr}$ (III), Fe (III), Fe (II) and Ni (II), Transition Metal Cations in Ammonium Alum-Urea Room Temperature Ionic Liquid", J. AlNahrain university, 16(3), 46-55, 2013.

[12] Hadi M. A. Abood, Andrew P. Abbott, Andrew D. Ballantyne and Karl S. Ryder "Do All Ionic Liquids need Organic Cations? Characterisation of $\left[\mathrm{AlCl}_{2} \cdot n \mathrm{Amide}\right]^{+} \mathrm{AlCl}_{4}{ }^{-}$and Comparison with Imidazolium Based Systems", $J$. Chem. Commun., 47(12), 3523-3525, 2011.

[13] International Center of Diffraction Data (ICDD), 81-1835. Holzar J., McCarthy G.; North Dokota State University, Frago, North Dokota, USA, Grant-in-Aid, 1991.

[14] F. Bustanafruz, M. Jafar-Tafreshi and M.Fazil, "Studies on Thermal Decomposition of Aluminum Sulfate to produce Alumina Nano Structure", $J$. nanostructures, 2, 463-468, 2013.

[15] International Center of Diffraction Data (ICDD),42-1429. Zacek, V.; Acta Univ. Carol., Geol., 315, 1988. 
[16] Peter A. and Julio D. Paula; "Physical Chemistry", Oxford University press, $8^{\text {th }} e d$, 1013, 2006.

[17] Allan Maccoll, J. Aspden and R. A. Ross, "Homogeneous Gas-Phase Pyrolysis of Acetamide", J. Trans. Faraday Soc., 64, 965-976, 1968

[18] Tanchi S., "Thermal Decomposition of Inorganic and Organic Salts of Aluminum and Thermal Transformation of formed Aluminas", J. Netsu Sokutei Jpn., 13(3), 113-122, 1986.

[19] Tokmakov I.V., Alavi S. and Thompson D.L., "Urea and Urea Nitrate Decomposition Pathways: A Quantum Chemistry Study", J. Phys. Chem. A, 8, 2759-2770, 2006.

[20] Jiain P. Chen, and Kimio I., "Thermal Decomposition of Urea and Urea Derivatives by Simultaneous TG/(DTA)/MS", J. Mass Spectrom. Soc. Jpn., 46(4), 299-303, 1998.

[21] Vanessa K. Peterson, "Diffraction Investigations of Cement Clinker and Tricalcium Silicate Using Rietveld Analysis", Ph.D. thesis, Materials and Forensic Sciences University of Technology, Sydney, 2003.

[22] Frank E., Sheriff Z. E.; "Air and Water Stable Ionic Liquids in Physical Chemistry" J. Phys. Chem. Chem. Phys., 8, 2101-2116, 2006.

[23] Fukumoto K., Yoshizawa M. and Ohno H.; "Room Temperature Ionic Liquids from 20 Natural Amino Acids", J. Am. Chem. Soc., 127, 2398-2399, 2005.

[24] Mohd B. A. Rahman, Khairulazhar J., Mahiran B., Emilia A., Kamaliah S. and Abu B. Salleh, "Synthesis and PhysicoChemical Properties of New Tetraethylammonium-based Amino Acid Chiral Ionic Liquids", J. Molecules, 15, 2388-2397, 2010.

[25] Jing Y., Qinghua Z., Laiying Z., Shiguo Z., Jian L., Xiaoping Z. and Youquan D.; "Novel Ionic Liquid Crystals based on $\mathrm{N}$ Alkylcaprolactam as Cations", J. Chem. Mater., 19(10), 2544-2550, 2007.

[26] L. Moens and D. M. Blake, "Advanced Heat Transfer and Thermal Storage Fluids", J. National Renewable Energy Laboratory, NREL/CP-510-37083, 2005.
[27] Vasishta D. Bhatt and Kuldip G.," Performance Evaluation of Solar Cooker using some $\left[\mathrm{N}^{+}{ }_{4444}\right]$ based Ionic Liquids as Thermal Energy Storage Materials", J. Adv. Mat. Lett., 4(4), 277-282, 2013.

[28] Subbiah S., Venkatesan S., Ming-Chung T. and Yen-Ho Ch.; "Review on The Chemical Stabilities of Ionic Liquids", $J$. Molecules, 14, 3780-3813, 2009.

[29] Swatloski R.P., Holbrey J.D., Rogers R.D.; "Ionic Liquids are not always Green: Hydrolysis of 1-Butyl-3-MethylImidazolium Hexafluorophosphate", $J$. Green Chem., 5, 361-363, 2003.

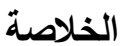

درست خواص بعض السوائل الايونية بدرجة حرارة الغرفة كوسائط خازنة وناقلة للحرارة في التطبيقات الحرارية لخمسة سوائل ايونية محضرة من شب الامونيوم كملح لاعضوي مع

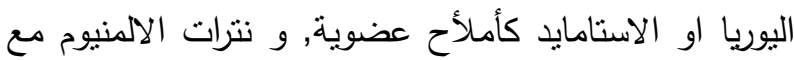
أملاح اليوريا او الاستاميد في نسبتين موليتن وتم استخدام التحليل الحراري الوزني, المسعر الحراري التفاضلي, حيود الاثعة السينية, طيف الاشعة تحت الحمراء, ومقياس التوصيلية الكهربائية. كما تمت دراسة الخواص الفيزيائيةالحرارية كالانثالبي, الحرارة النوعية وسعة خزن الطاقة لاقلة الحرارية. وامتازت السوائل الايونية لشب الامونيوم-يوريا بالنسبة المولية (1:0) ولنترات الالمنيوم-استامايد بالنسبة المولية (Y:1) بكثافة عاليه, مدى سائل حراري واسع, استقرارية كيميائية عالية, حرارة نوعية عالية, و سعه خزن الطاقة الحرارية عالية. بالاعنماد على النتائج التجريبية, استتتج انه السوائل الايونية هي مرشحة جيدة كوسائط خازنة

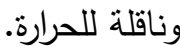

